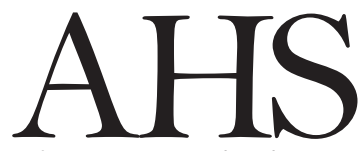

Advances in Horticultural Science

\title{
Biochemical changes in pear fruits during storage at ambient conditions
}

\author{
A. $\operatorname{Kaur}^{1(*)}$, S. Sharma ${ }^{1}$, N.P. Singh ${ }^{2}$ \\ 1 Department of Biochemistry, Punjab Agricultural University, 141004 \\ Ludhiana, Punjab, India. \\ 2 Department of Fruit Science, Punjab Agricultural University, 141004 \\ Ludhiana, Punjab, India.
}

Key words: Cellulase, minerals, 'Patharnakh', pectinmethylestrase, polygalacturonase, 'Punjab Beauty', quality attributes, ripening physiology, sugars.

OPEN ACCESS

(*) Corresponding author: avninderkaur12@gmail.com

Citation:

KAUR A., SHARMA S., SINGH N.P., 2021 -

Biochemical changes in pear fruits during storage at ambient conditions. - Adv. Hort. Sci., 35(3): 293-303

\section{Copyright:}

(c) 2021 Kaur A., Sharma S., Singh N.P. This is an open access, peer reviewed article published by Firenze University Press

(http://www.fupress.net/index.php/ahs/) and distributed under the terms of the Creative Commons Attribution License, which permits unrestricted use, distribution, and reproduction in any medium, provided the original author and source are credited.

Data Availability Statement:

All relevant data are within the paper and its Supporting Information files.

Competing Interests:

The authors declare no competing interests.

Received for publication 31 March 2021 Accepted for publication 3 August 2021
Abstract: 'Patharnakh' (PN) (Pyrus pyrifolia Burm. Nakai) and 'Punjab Beauty' (PB) [Pyrus communis L. $\times$ Pyrus pyrifolia Burm. (Nakai)] are leading low-chill pear cultivars of subtropics of India. Diurnal temperature and relative humidity during fruit harvest period is high which considerably affect the shelf life of fruits. Fruits of 'PN' and 'PB' pear harvested at physiological maturity were stored for 12 days at ambient temperature and effects of storage temperature on physical and qualitative parameters were studied. Both cultivars showed reduction in fruit weight and firmness, reducing sugars, sucrose, starch and pectin content. However, total soluble solids and juice acid content increased during storage. Sucrose synthase activity and sucrose content showed significant positive correlation in ' $\mathrm{PN}$ ' cultivar. Activities of fruit softening enzymes such as polygalacturonase (PG) and cellulase was enhanced; whereas, pectinmethylesterase (PME) was reduced during storage. Fruit firmness was negatively correlated with PG in both the cultivars. In 'PN' cultivar, fruit firmness was positively correlated with cellulase and negatively with PME enzyme but reverse trend was observed in 'PB' cultivar. Fruit minerals content didn't show any substantial disparities in both the cultivars during storage. 'Patharnakh' and 'Punjab Beauty' fruits maintain desirable quality parameters up to 6-9 days and 3-6 days, respectively, during storage at ambient conditions.

\section{Introduction}

Pear (Pyrus spp.) ranks second next to apple fruit crop in the world in terms of area, production and varietal wealth among temperate fruits. It belongs to the family Rosaceae and sub family Pomoideae. In India, it is cultivated in Himachal Pradesh, Uttarakhand, Punjab, Jammu \& Kashmir and some parts of Assam and Nilgiris hills. In Punjab province of NorthWest India, the area under pear cultivation is dominated by low chill cultivar 'Patharnakh' that belongs to Oriental or Sand pear group (Pyrus pyrifolia Burm. Nakai) and semi soft pear cultivar 'Punjab Beauty, a hybrid between Pyrus communis L. $\times$ Pyrus pyrifolia Burm. (Nakai) (Sharma and 
Singh, 2011) and fruits are harvested at physiological maturity during $\mathrm{II}^{\text {nd }}$ fortnight of July. Diurnal temperature and relative humidity during fruit harvest period is high which considerably affect the shelf life of fruits. It is documented that pear fruits have postharvest shelf-life of about 10 days at ambient conditions $\left(25-30^{\circ} \mathrm{C}\right)$ and quality related parameters are reduced rapidly during storage (Nath et al., 2011). After harvest, consumers' preference and market price depends on fruit's attractive colour, flavor, taste, aroma and firmness. The variability observed in volatile organic compounds, physico-chemical and sensory parameters can be used to understand the ripening behavior of pear cultivars (Taiti et al., 2017). It is suggested that fruits should be harvested at optimal physiological maturity and kept under optimal storage conditions to enhance the shelf life of fruits (Hafez et al., 2019). Fruit quality deteriorates after harvest due to rapid change in respiration, activity of cell wall degradation enzymes and infestation of pathogens during transportation and storage (Ge et al., 2017).

The quality related attributes constantly depend on the storage temperature which primarily affect fruit freshness and shelf life. Quantification of organic acids and soluble sugars (sucrose, glucose and fructose) are correlated to the production of quality fruits (Itai and Tanahashi, 2008). Sugars content in pear fruit improve during early storage period and further decline with the advancement of storage period at ambient conditions is due to fermentation into alcoholic content (Kaur and Dhillon, 2015). Softening is associated with the degradation of cell wall polysaccharides and biosynthesis of cellulase, polygalacturonase and pectin methyl esterase enzymes (Zhou et al., 2011). Fruit minerals content can also modify the quality attributes and storability (Saquet et al., 2019). It is well recognized fact that pome fruits are harvested at proper maturity stage and must be stored under explicit low temperature to extend the shelf life without exhibiting any deterioration in fruit quality attributes (Itai et al., 2015; Yu et al., 2016). However, less information is available on the ripening behavior of pear fruits harvested at physiological maturity (135 DAFS) and kept in ambient conditions and subsequently, its effect on the biochemical composition during storage. Therefore, the study was performed to record the changes in physical characteristics, sugars composition, activities of hydrolytic fruit softening enzymes and minerals profile during storage of pear fruits at ambient conditions.

\section{Materials and Methods}

\section{Experimental procedure}

Fruits of 'Patharnakh' 'PN' and 'Punjab Beauty' 'PB' cultivars (Fig. 1) grafted on Kainth rootstock (Pyrus pashia) were harvested during II $^{\text {nd }}$ fortnight of July (135-145 days after fruit set; DAFS) from the orchard situated at Research Farm, Department of Fruit Science, Punjab Agricultural University, Ludhiana (India) $\left(30.90^{\circ} \mathrm{N}, 75.86^{\circ} \mathrm{E}\right)$. Fifteen fruits/replication free from any type of visual injury and bruises of each cultivar were washed with sodium hypochlorite $4 \%\left(2.5 \mathrm{ml} \mathrm{L}^{-1}\right)$ solution for $5 \mathrm{~min}-$ utes (PAU, 2020). Fruits were dried in shade and packed in three ply corrugated fiberboard with $5 \%$ perforation and stored at ambient temperature $\left(28 \pm 2^{\circ} \mathrm{C}\right)$. Physico-chemical parameters, physiological changes and enzymatic activities were estimated after the intervals of $0,3,6,9$ and 12 days of storage.

\section{Physiological loss in weight (PLW)}

Fruits stored at ambient temperature were weighed before storage and at a subsequent storage interval. The values were expressed as PLW (\%) (Singh et al., 2021).

\section{Fruit firmness}

Fruit firmness was measured at every storage

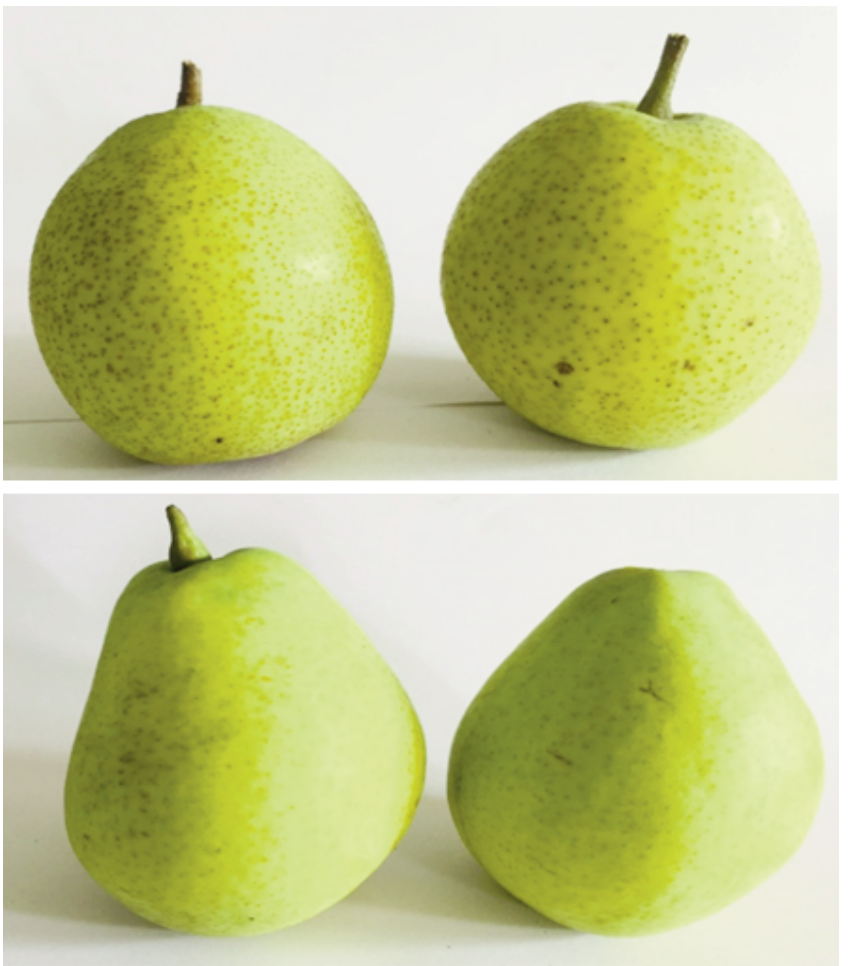

Fig. 1 - Fruits of 'PatharNakh' (top) and 'Punjab Beauty' (bottom) cultivars at physiological maturity. 
interval with penetrometer (Model No. FT-327, QA Supplies LLC, USA) and values were expressed Ibs (Mahajan et al., 2010).

Total soluble solids, Titratable acidity and fruit color coordinates

Titratable acidity (TA) was determined with titration method described by Ranganna (2007) and expressed as percent of maleic acid. Fruit color coordinates $\left(L^{*}, a^{*}, b^{*}, C^{*}\right.$ and $\left.h^{*}\right)$ were randomly measured on two opposite sites at fruit equator using Color Flex Spectrophotometer (Hunter Lab Color Flex, Hunter Associates Inc., Reston, VA, USA). These coordinates were expressed in CIE units (Hunter, 1975).

\section{Sugars}

Fruit pulp was homogenized with $80 \%$ ethanol and refluxed twice for $20 \mathrm{~min}$. The supernatants were pooled to evaporate ethanol and volume was made $10 \mathrm{ml}$ with distilled water. This extract was used for the estimation of reducing sugars, fructose and sucrose by the methods already described by Kaur et al. (2018). For the estimation of fructose, $0.1 \%$ resorcinol reagent and $30 \% \mathrm{HCl}$ were added to sugar extract and color intensity was recorded at 540 $\mathrm{nm}$. Estimation of sucrose was done using the same procedure except that free fructose was destroyed by treating the sample with $6 \% \mathrm{KOH}$ and the absorbance was measured at $490 \mathrm{~nm}$. The residue left after sugar extraction was dried and treated with perchloric acid to hydrolyze starch into simpler sugars and were estimated using the method of Dubois et al. (1956).

\section{Sucrose metabolizing enzymes}

Enzymes viz. sucrose synthase (SS), sucrose phosphate synthase (SPS) and invertases (acid and neutral) were extracted from fruit pulp using HEPES$\mathrm{NaOH}$ buffer ( $\mathrm{pH} 7.5)$ and assayed by the methods described by Asthir and Singh (1995) and Singh et al. (1978). For SS assay, $0.1 \mathrm{ml}$ fructose $(150 \mathrm{mM}), 0.1$ $\mathrm{ml}$ UDPG solution $(20 \mathrm{mM})$ and $0.2 \mathrm{ml}$ enzyme extract were incubated for $30 \mathrm{~min}$ at $37^{\circ} \mathrm{C}$, followed by addition of $0.1 \mathrm{ml}$ of $30 \% \mathrm{KOH}$ and contents were boiled. Added $1 \mathrm{ml}$ resorcinol reagent and $3 \mathrm{ml}$ of $\mathrm{HCl}$ and tubes were kept for $10 \mathrm{~min}$ at $80^{\circ} \mathrm{C}$. After cooling the tubes, the absorbance was noted at $490 \mathrm{~nm}$. For SPS assay, fructose-6-phosphate (150 mM) was used as substrate and enzyme activity was expressed as $\mathrm{mg}$ sucrose formed $\mathrm{g}^{-1} \mathrm{~min}^{-1}$ fresh weight ( $\mathrm{fw}$ ). For acid invertase, $0.6 \mathrm{ml}$ sodium acetate buffer $(0.2 \mathrm{M}$, $\mathrm{pH} 4.8), 0.2 \mathrm{ml}$ sucrose $(50 \mathrm{mM})$ and $0.2 \mathrm{ml}$ of enzyme extract were incubated for $1 \mathrm{~h}$ at $37{ }^{\circ} \mathrm{C}$ followed by addition of $1 \mathrm{ml}$ Nelson reagent $\mathrm{C}$. Contents were boiled for $20 \mathrm{~min}$ and then $1 \mathrm{ml}$ Nelson reagent $\mathrm{D}$ and $7 \mathrm{ml}$ of distilled water was added and mixed well. Absorbance was read at $510 \mathrm{~nm}$. Sodium phosphate buffer $(0.2 \mathrm{M}, \mathrm{pH} 7.5)$ was used for neutral invertase assay in place of acetate buffer and rest of the procedure was same as described for acid invertase. Invertase activity was expressed as $\mathrm{mg}$ glucose formed $\min ^{-1} \mathrm{~g}^{-1} \mathrm{fw}$.

\section{Pectin content and cell wall degrading enzymes}

For pectin content, $50 \mathrm{~g}$ fruit pulp and $50 \mathrm{ml}$ of $0.01 \mathrm{~N} \mathrm{HCl}$ were boiled for $30 \mathrm{~min}$ and supernatant was collected. The process was repeated twice using $0.05 \mathrm{~N}$ and $0.3 \mathrm{~N} \mathrm{HCl}$ and volume of filtrate was made to $100 \mathrm{ml}$. Two $\mathrm{ml}$ of diluted extract was neutralized using $1 \mathrm{~N} \mathrm{NaOH}$. To this, calcium chloride was added next day for precipitation. Precipitates were collected, weighed and \% calcium pectate content was calculated (Okimasu, 1956). Fruit pulp was crushed with $0.1 \mathrm{M}$ sodium acetate buffer ( $\mathrm{pH} \mathrm{5.2)}$ and supernatant was used for the assay of cellulase and polygalacturonase enzymes. For cellulase, $1 \mathrm{ml}$ of $0.1 \mathrm{M}$

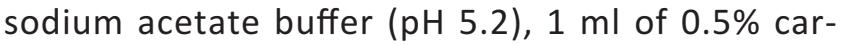
boxymethyl cellulose (prepared in buffer) and $1 \mathrm{ml}$ of enzyme extract were incubated for $1 \mathrm{~h}$ at $55^{\circ} \mathrm{C}$, one $\mathrm{ml}$ of dintrosalicyclic acid was added to terminate the reaction. The contents were boiled for $10 \mathrm{~min}$ and absorbance recorded at $560 \mathrm{~nm}$. Enzyme activity of cellulase was expressed as $\mathrm{mg}$ glucose released $\mathrm{min}^{-1}$ $\mathrm{g}^{-1} \mathrm{fw}$. Pectic acid $(0.5 \%)$ was used as substrate for PG assay and enzyme activity was expressed as $\mathrm{mg}$ galacturonic acid released $\mathrm{min}^{-1} \mathrm{~g}^{-1} \mathrm{fw}$ (Malik and Singh, 1980). Fruit tissue was crushed with $0.1 \mathrm{M}$ citrate phosphate buffer ( $\mathrm{pH}$ 5.0) and supernatant obtained was used for PME enzyme assay. For reaction, $2 \mathrm{ml}$ of $1 \%$ pectin, $2 \mathrm{ml}$ of $0.1 \mathrm{M}$ citrate phosphate buffer ( $\mathrm{pH} \mathrm{5.0)}$ and $1 \mathrm{ml}$ of enzyme extract were incubated at $35{ }^{\circ} \mathrm{C}$. From this reaction mixture, $1 \mathrm{ml}$ was pipetted out at 0 and $1 \mathrm{~h}$ of the incubation and titrated against $0.005 \mathrm{~N} \mathrm{NaOH}$. The PME activity was expressed as milliequivalents of methoxyl groups released $\mathrm{min}^{-1}$ by $1 \mathrm{ml}$ of enzyme (Balaban et al., 1991).

\section{Mineral's analysis}

For nitrogen $(\mathrm{N})$ estimation, dried powder of fruits was digested with $\mathrm{H}_{2} \mathrm{SO}_{4}$ and content were determined using Kjeldahl method (Gehrke et al., 1972). Phosphorus ( $P$ ) and potassium (K) in fruit samples were digested with a mixture of nitric acid and per- 
chloric acid. P estimation was done by the method described by Jackson (1973) and K by flame photometric method (AOAC, 1990). Nutrients like $\mathrm{Ca}, \mathrm{Mg}$, $\mathrm{Cu}, \mathrm{Zn}, \mathrm{Fe}$ and $\mathrm{Mn}$ were determined using atomic absorption spectrophotometer (Perkin Elmer Analyst 200). The instrument optimization, calibration and elemental analysis were carried out using WinLab32 software as described by Bradfield and Spencer (1965).

\section{Statistical analysis}

The experiment was conducted during the year 2020 in a complete randomized design with four replications. Two hundred and forty fruits of each cultivar for different storage intervals were stored at ambient temperature. A lot of 60 fruits for each storage interval with 15 fruits/replication were stored in cardboard boxes. The data was analyzed by one-way analysis of variance. The differences were considered statistically significant at the level $P$ value of $<0.05$ using software CPCS1 developed by PAU, Ludhiana and WASP 2.0. Experimental data was represented as mean \pm standard error. The data were subjected to Pearson's correlation analysis to assess the relationship between attributes. Principal component analysis (PCA) was used to examine the interrelations between different quality parameters.

\section{Results}

\section{Physical characteristics}

Physiological loss in Weight (PLW) of 'Patharnakh' (PN) and 'Punjab Beauty' (PB) pear cultivars increased during different storage intervals and the higher rate up to 4.75 to $8.18 \%$ was noted in 'PB' between 6 to 9 days compared to 3.21 to $4.16 \%$ in 'PN' at ambient storage conditions (Fig. 2A). The values of reduction in fruit firmness were increased with advancement of the storage period in both the cultivars. The rate of softening of ' $P N$ ' fruits was lower than that of ' $P B^{\prime}$ ' fruits and values were higher between 6 to 9 days in 'PN' and 3-6 days in 'PB' culti$\operatorname{var}$ (Fig. 2B). During storage, values ranged from 11.6 Ibs at 0 day to $9.35 \mathrm{lbs}$ at 12 days in 'PN' and 10.75 Ibs at 0 day to $8.38 \mathrm{lbs}$ at 12 days in 'PB'.

\section{Total soluble solids and Titratable acidity}

TSS content increased in 'PB' fruits during storage with the mean value of $14.97^{\circ} \mathrm{Brix}$ and a significant rise in values was recorded from $13.39^{\circ}$ Brix at 3 DAS to $16.98^{\circ}$ Brix at 9 DAS (Fig. 2C). 'PN' cultivar showed significant variations in TSS content up to 6 days after storage and values varied from $11.05^{\circ}$ Brix to $11.63^{\circ}$ Brix. There was a significant increase in juice acid content from 3 DAS to 9 DAS and then values remained almost comparable until 12 days of storage in both the cultivars (Fig. 2D). 'PB' showed higher acidity values at all the storage intervals as compared to 'PN' cultivar.
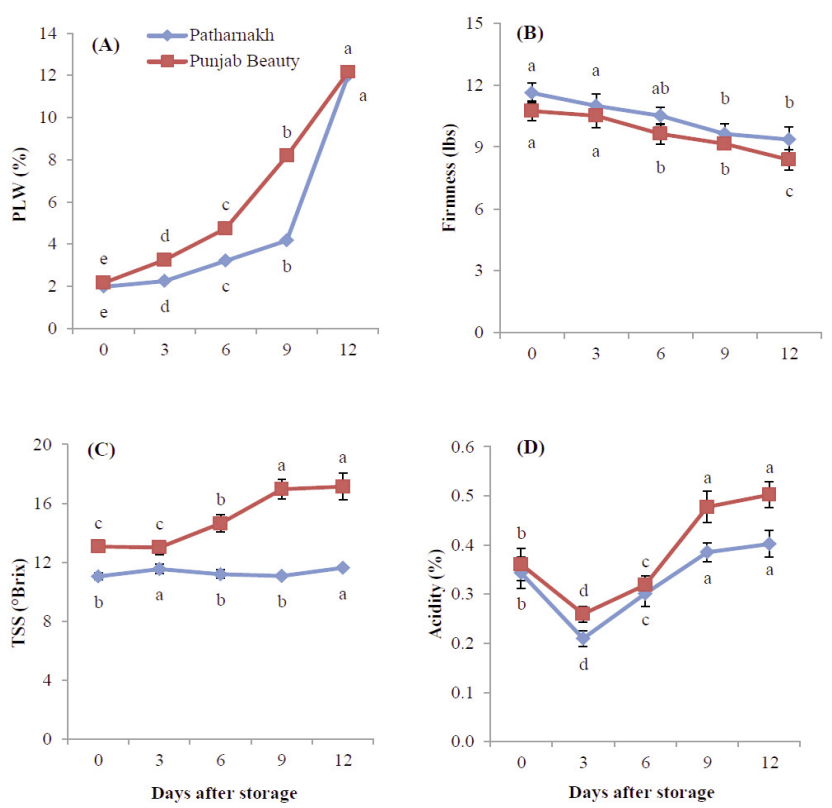

Fig. 2 - Changes in physiological loss in weight (A), fruit firmness (B), TSS (C) and titratable acidity (D) of pear fruits during storage at ambient conditions. Vertical bars represent \pm $\mathrm{SE}$ of means for 4 replicates. Different letters indicate the significant differences among storage periods according to WASP $2.0(P \leq 0.05)$.

\section{Fruit color}

Color coordinates depicting peel color where $\mathrm{L}^{*}$ expresses as lightness, a* positive value measures the red intensity and negative value as green color; $b^{*}$ positive value measures yellow color intensity. The value of $b^{*}$ coordinate was improved in both the pear cultivars during storage being highest in 'PB' and lowest in 'PN' cultivar. However, hue angle $(h *)$ showed the reverse trend (Table 1). Significant improvement in a* values from 9 to 12 DAS in 'PN' cultivar was observed; however, other color coordinates showed non-significant variations when the storage period was increased from 3 to 12 days. Initial negative $a^{*}$ values indicated greener colour at zero day as compared to 12 days of storage in 'PN' cultivar. 
Table 1 - Changes in fruit color coordinates of pear fruits during storage at ambient conditions

\begin{tabular}{|c|c|c|c|c|c|c|}
\hline \multirow{2}{*}{ Fruit color } & \multicolumn{5}{|c|}{ Days after storage } & \multirow{2}{*}{$C D(P<0.05)$} \\
\hline & 0 & 3 & 6 & 9 & 12 & \\
\hline \multicolumn{7}{|c|}{ 'Patharnakh' (PN) } \\
\hline$L^{*}$ & $59.00 \pm 4.24$ & $61.12 \pm 1.91$ & $64.61 \pm 2.10$ & $66.07 \pm 2.54$ & $67.20 \pm 2.19$ & NS \\
\hline$a^{*}$ & $-1.50 \pm 1.22$ & $-2.26 \pm 1.05$ & $-0.83 \pm 1.62$ & $0.17 \pm 0.58$ & $3.24 \pm 1.40$ & 1.86 \\
\hline$b^{*}$ & $41.54 \pm 2.65$ & $40.90 \pm 2.12$ & $43.90 \pm 1.36$ & $46.09 \pm 1.03$ & $50.37 \pm 1.74$ & NS \\
\hline$C^{*}$ & $41.58 \pm 2.68$ & $40.97 \pm 2.16$ & $43.92 \pm 1.38$ & $46.09 \pm 1.03$ & $50.49 \pm 1.69$ & NS \\
\hline$h^{*}$ & $92.00 \pm 1.59$ & $93.13 \pm 1.37$ & $91.03 \pm 2.09$ & $89.78 \pm 0.72$ & $86.30 \pm 1.66$ & NS \\
\hline \multicolumn{7}{|c|}{ 'Punjab Beauty' (PB) } \\
\hline $\mathrm{L}^{*}$ & $65.34 \pm 1.52$ & $63.49 \pm 2.42$ & $63.44 \pm 1.72$ & $68.45 \pm 0.82$ & $66.67 \pm 1.17$ & NS \\
\hline$a^{*}$ & $3.59 \pm 2.35$ & $4.49 \pm 1.16$ & $4.14 \pm 2.74$ & $1.88 \pm 1.19$ & $-0.89 \pm 0.54$ & NS \\
\hline$b^{*}$ & $41.38 \pm 1.58$ & $43.25 \pm 2.79$ & $43.09 \pm 1.07$ & $47.84 \pm 1.39$ & $52.16 \pm 2.00$ & NS \\
\hline$C^{*}$ & $41.57 \pm 1.66$ & $43.49 \pm 2.85$ & $43.35 \pm 1.20$ & $47.88 \pm 1.39$ & $52.16 \pm 2.00$ & NS \\
\hline$h^{*}$ & $94.93 \pm 3.14$ & $95.89 \pm 1.32$ & $95.42 \pm 3.59$ & $92.25 \pm 1.44$ & $90.96 \pm 0.55$ & NS \\
\hline
\end{tabular}

Carbohydrate composition and Sucrose metabolizing enzymes

Reducing sugars increased up to 3 DAS in 'PN' and 6 DAS in 'PB' fruits and then declined during advanced storage period (Fig. 3A). Fructose content increased in pear fruits from harvest to 6 DAS and later showed a declining trend up to 12 DAS in both the cultivars (Fig. 3B). In 'PB' fruits, sucrose content did not show any differences until 9 days of storage and values were declined at 12 DAS (Fig. 3C). Starch
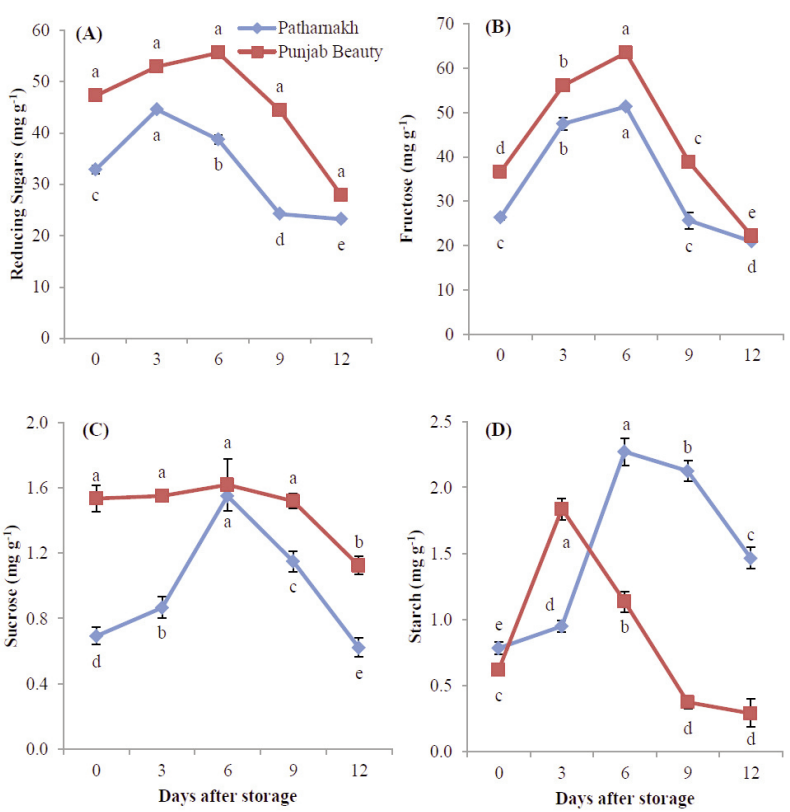

Fig. 3 - Changes in reducing sugars (A), fructose (B), sucrose (C) and starch (D) content of pear fruits during storage at ambient conditions. Vertical bars represent \pm SE of means for 4 replicates. Different letters indicate the significant differences among storage periods according to WASP $2.0(\mathrm{P} \leq 0.05)$. content increased initially until 3 days and then showed declined trend up to final storage interval (Fig. 3D). Both starch and sucrose content improved up to 6 DAS and a decrease in its content was observed from 6 to 12 DAS in 'PN' fruits.

Sucrose synthase (SS) enzyme showed fluctuation in values in both the cultivars with the advancement of storage period (Fig. 4A). After 12 days of storage; SS activity was about 2-fold higher in ' $P B^{\prime}$ ' than 'PN' fruits. In 'PN' cultivar, sucrose phosphate synthase
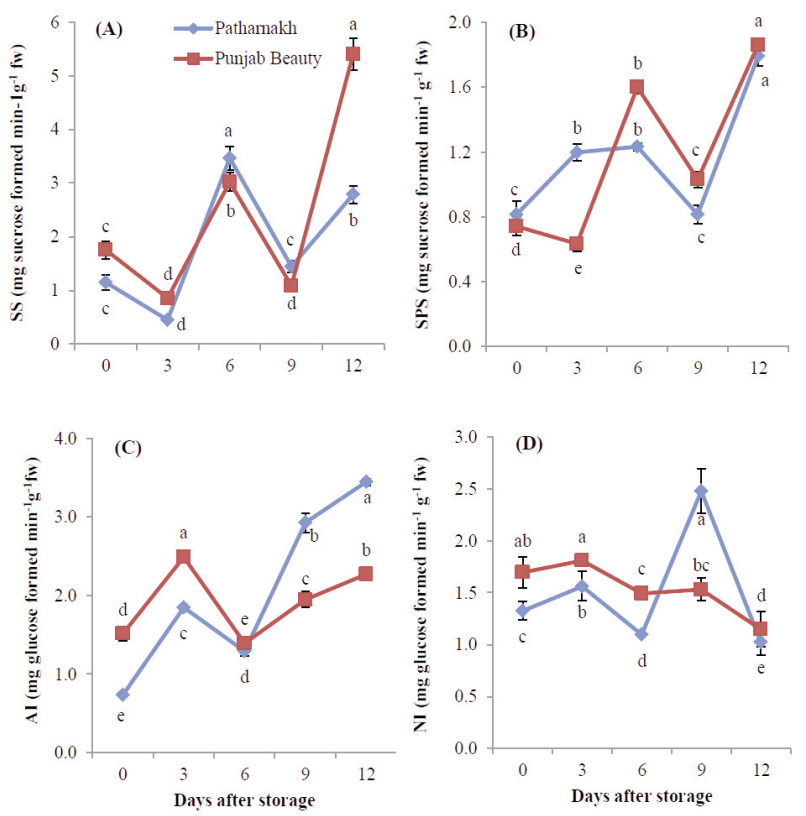

Fig. 4 - Variations in activities of sucrose metabolizing enzymes: SS (A), SPS (B), AI (C) and NI (D) of pear fruits during storage at ambient conditions. Vertical bars represent $\pm \mathrm{SE}$ of means for 4 replicates. Different letters indicate the significant differences among storage periods according to WASP $2.0(\mathrm{P} \leq 0.05)$. 
(SPS) activity increased at 3 DAS and exhibited a steady variation with less effectiveness until 6 DAS. In 'PB' cultivar, SPS activity during initial storage period decreased significantly and later showed an upsurge to 6 th DAS by 1.5 -fold from the initial values and comparably had higher values than 'PN' cultivar. At 6 DAS, both cultivars showed a decline in SPS enzyme activity up to 9 days of storage followed by an upsurge up to 12 DAS (Fig. 4B). Acid invertase (AI) activity increased from 0 to 3 DAS in both the cultivars and subsequently declined at 6 DAS followed by a significant enhancement with progression in storage at ambient temperature (Fig. 4C). Neutral Invertase ( $\mathrm{NI}$ ) activity increased up to 3 days of storage followed by a declining trend after 6 days of storage in both the cultivars. In 'PN' cultivar, $\mathrm{NI}$ activity increased until 9 DAS but decreased progressively afterwards. In 'PB' cultivar, NI activity decreased from 3 to 12 DAS (Fig. 4D). In both the cultivars, reducing sugars, fructose and sucrose attributes were correlated positively (data not shown). These sugars presented non-significant negative relationships with PLW except in reducing sugars with PLW $(r=-0.483 ; p$ $\leq 0.05)$. In 'PN' cultivar, substantially positive correlation between sucrose accumulation and SS activity $(r=0.46 ; p \leq 0.05)$ and non-significant correlation with SPS ( $r=0.09$ ) was observed (Table 2). In 'PB' cultivar, sucrose exhibited negative correlation with SS ( $r=$ $0.73, p \leq 0.01)$ and SPS ( $r=-0.54, p \leq 0.05)$. Al activity was non-significantly and negatively correlated with sucrose accumulation in 'PN' $(r=-0.38)$ and 'PB' $(r=-$ 0.43 ) cultivar. $\mathrm{NI}$ activity and sucrose content were negatively correlated in both pear cultivars.

\section{Pectin and cell wall degrading enzymes}

Total pectin content was decreased significantly in both the cultivars during storage (Fig. 5A). PG activity increased significantly in both the cultivars during progression of storage period and values were 1.54 and 2.12-fold higher during last storage period com- pared to harvest stage in ' $P N^{\prime}$ ' and ' $P B$ ', cultivars, respectively (Fig. 5B). Cellulase activity also enhanced in pear fruits during storage but showed a significant declining trend from 6 to 12 days of storage in both the cultivars under ambient conditions (Fig. 5C). PME activity was 1.18 ('PN') and 1.24-fold ('PB') lower until 6 days of storage period (Fig. 5D). Thereafter, an increment in PME activity up to 12 DAS was noticed in both the cultivars.

In 'PB', fruit firmness was negatively correlated to cellulase $(r=-0.632)$ and PG $(r=-0.857)$ activities and values were significant at $1 \%$ level of significance. PME activity was positively correlated to firmness in these fruits $(r=0.450)$ at $5 \%$ level of significance dur-
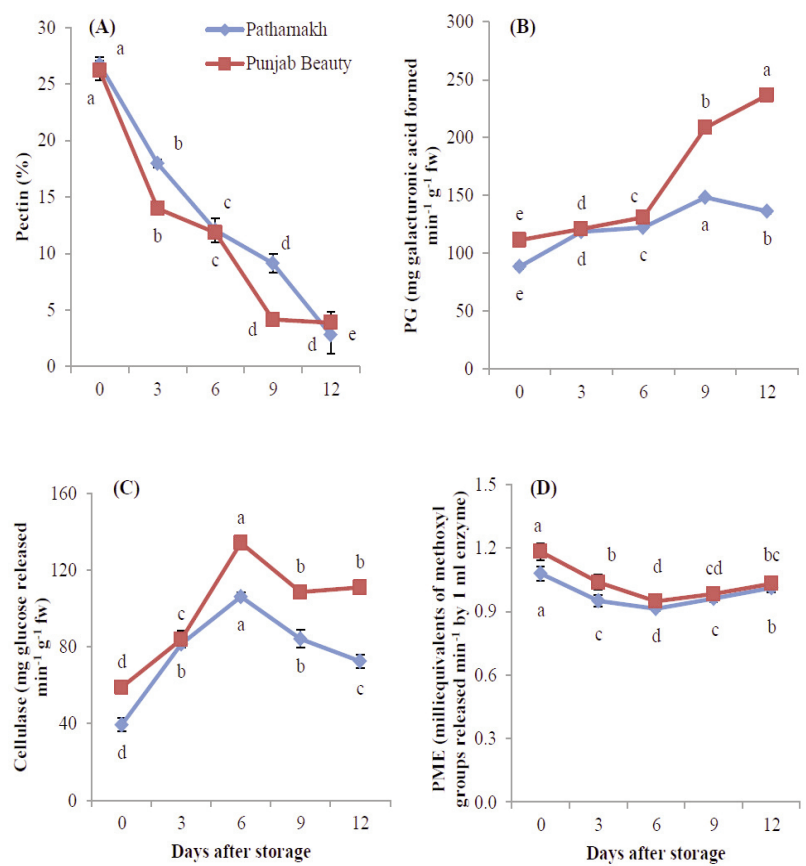

Fig. 5 - Changes in activities of cell wall degrading enzymes as Pectin (A), PG (B), cellulase (C) and PME (D) in pear fruits during storage at ambient conditions. Vertical bars represent \pm SE of means for 4 replicates. Different letters indicate the significant differences among storage periods according to WASP $2.0(\mathrm{P} \leq 0.05)$.

Table 2 - Correlation between sucrose metabolizing enzymes and sucrose accumulation in pear cultivars during storage

\begin{tabular}{|c|c|c|c|c|c|c|c|c|}
\hline \multirow{2}{*}{ Traits } & \multicolumn{4}{|c|}{ 'Patharnakh' } & \multicolumn{4}{|c|}{ 'Punjab Beauty' } \\
\hline & Sucrose & SS & SPS & Al & Sucrose & SS & SPS & Al \\
\hline Sucrose synthase & $0.460^{*}$ & & & & $-0.730^{*}$ & & & \\
\hline Sucrose phospate synthase & 0.085 & $0.766^{* *}$ & & & $-0.543^{*}$ & $0.632 *$ & & \\
\hline Acid invertase & -0.376 & 0.405 & $0.529 *$ & & -0.427 & $0.486^{*}$ & -0.109 & \\
\hline Neutral invertase & -0.372 & $-0.053^{*}$ & $-0.617 * *$ & 0.267 & $-0.723 * *$ & $-0.597 * *$ & $-0.835 * *$ & -0.024 \\
\hline
\end{tabular}

* Correlation is significant at the $p \leq 0.05$.

** Correlation is significant at $p \leq 0.01$. 
ing storage at ambient conditions. In 'PN' fruits, PG activity showed a significant negative correlation with fruit firmness $(r=-0.738, P \leq 0.01)$ and PME ( $r=-$ $0.523, P \leq 0.05$ ) and a positive correlation with cellulase enzyme $(r=0.624, P \leq 0.01)$.

\section{Minerals}

Nitrogen content decreased significantly at 3 DAS by 1.6 -fold in both the cultivars and then increased from 6 to 12 DAS (Table 3). Phosphorus content in both the pear cultivars varied non-significantly during storage. Potassium content in 'PN' significantly increased between 3 to 6 days of storage period and then values remained higher until 12 DAS in both the cultivars. Magnesium content in both the cultivars showed almost similar pattern during storage intervals and significantly lower values at 12 DAS in 'PN' and at 9 DAS in 'PB' fruits were observed. Calcium content in fruits of both the cultivars enhanced significantly until 3 DAS. Iron and zinc content decreased significantly in both the cultivars from harvest to 12 days of storage periods under ambient conditions (Table 4); whereas, manganese content displayed a reverse trend in 'PB' fruits. Copper content was substantially lower during different storage intervals in comparison to harvest stage in both the cultivars.

Principal component analysis (PCA)

Biplot for PC1 and PC2 in pear fruits are given in figure 6 . The results showed that first two components explained $62.8 \%$ and $71.4 \%$ of the total variability in 'PN' and 'PB' cultivars, respectively. In 'PN' cultivar, PC1 includes sucrose, cellulase, starch, PG, $\mathrm{Al}$ and acidity attributes which explained $35.9 \%$ of total variability. PC2 comprises reducing sugars, fructose, firmness, pectin, and PME parameters and showed total variability of about $26.9 \%$ (Fig. 6A). In 'PB' cultivar, PC1 includes cellulase, SPS, TSS, PG and acidity characteristics that described $51.8 \%$ of total variability. PC2 comprises reducing sugars, fructose, sucrose, starch, $\mathrm{NI}$, firmness, pectin and PME that described $19.6 \%$ of the total variability in physicochemical parameters in 'PB' cultivar during storage at ambient conditions (Fig. 6B).

\section{Discussion and Conclusions}

Physiological loss in weight (PLW) consists of metabolic activities, respiration and transpiration,

Table 3 - Macrominerals (\%) content in pear fruits during storage at ambient conditions

\begin{tabular}{|c|c|c|c|c|c|c|c|c|c|c|}
\hline \multirow{2}{*}{$\begin{array}{l}\text { Days } \\
\text { after } \\
\text { storage }\end{array}$} & \multicolumn{2}{|c|}{ N } & \multicolumn{2}{|c|}{$\mathrm{P}$} & \multicolumn{2}{|c|}{ K } & \multicolumn{2}{|c|}{$\mathrm{Mg}$} & \multicolumn{2}{|c|}{$\mathrm{Ca}$} \\
\hline & 'Patharnakh' & $\begin{array}{l}\text { 'Punjab } \\
\text { Beauty' }\end{array}$ & 'Patharnakh' & $\begin{array}{l}\text { 'Punjab } \\
\text { Beauty' }\end{array}$ & 'Patharnakh' & $\begin{array}{l}\text { 'Punjab } \\
\text { Beauty' }\end{array}$ & 'Patharnakh' & $\begin{array}{l}\text { 'Punjab } \\
\text { Beauty' }\end{array}$ & 'Patharnakh' & $\begin{array}{l}\text { 'Punjab } \\
\text { Beauty' }\end{array}$ \\
\hline 0 & $0.11 \pm 0.01$ & $0.13 \pm 0.01$ & $2.95 \pm 0.09$ & $2.68 \pm 0.24$ & $0.93 \pm 0.06$ & $1.07 \pm 0.06$ & $1.48 \pm 0.02$ & $1.45 \pm 0.01$ & $0.57 \pm 0.02$ & $0.47 \pm 0.03$ \\
\hline 3 & $0.07 \pm 0.00$ & $0.08 \pm 0.00$ & $2.91 \pm 0.14$ & $2.48 \pm 0.20$ & $0.83 \pm 0.06$ & $1.07 \pm 0.06$ & $1.49 \pm 0.02$ & $1.42 \pm 0.04$ & $0.68 \pm 0.02$ & $0.62 \pm 0.03$ \\
\hline 6 & $0.12 \pm 0.01$ & $0.09 \pm 0.01$ & $2.88 \pm 0.14$ & $2.65 \pm 0.05$ & $1.20 \pm 0.00$ & $1.03 \pm 0.06$ & $1.48 \pm 0.02$ & $1.44 \pm 0.03$ & $0.39 \pm 0.02$ & $0.33 \pm 0.03$ \\
\hline 9 & $0.12 \pm 0.00$ & $0.12 \pm 0.01$ & $2.74 \pm 0.11$ & $2.58 \pm 0.11$ & $1.17 \pm 0.06$ & $1.20 \pm 0.10$ & $1.43 \pm 0.04$ & $1.19 \pm 0.05$ & $0.47 \pm 0.02$ & $0.32 \pm 0.01$ \\
\hline 12 & $0.13 \pm 0.00$ & $0.13 \pm 0.00$ & $2.72 \pm 0.12$ & $2.42 \pm 0.09$ & $1.40 \pm 0.10$ & $1.17 \pm 0.06$ & $1.30 \pm 0.02$ & $1.36 \pm 0.07$ & $0.28 \pm 0.00$ & $0.25 \pm 0.01$ \\
\hline Mean & $0.11 \pm 0.00$ & $0.11 \pm 0.01$ & $2.84 \pm 0.12$ & $2.56 \pm 0.14$ & $1.11 \pm 0.05$ & $1.11 \pm 0.07$ & $1.43 \pm 0.02$ & $1.37 \pm 0.04$ & $0.48 \pm 0.02$ & $0.40 \pm 0.02$ \\
\hline$C D(P \leq 0.05)$ & 0.01 & 0.02 & NS & NS & 0.16 & NS & 0.05 & 0.08 & 0.04 & 0.05 \\
\hline
\end{tabular}

Table 4 - Microminerals ( $\mathrm{mg} \mathrm{kg}^{-1} \mathrm{dw}$ ) content in pear fruits during storage at ambient conditions

\begin{tabular}{|c|c|c|c|c|c|c|c|c|}
\hline \multirow{2}{*}{$\begin{array}{l}\text { Days } \\
\text { after } \\
\text { storage }\end{array}$} & \multicolumn{2}{|c|}{$\mathrm{Fe}$} & \multicolumn{2}{|c|}{$\mathrm{Zn}$} & \multicolumn{2}{|c|}{$\mathrm{Mn}$} & \multicolumn{2}{|c|}{$\mathrm{Cu}$} \\
\hline & 'Patharnakh' & 'Punjab Beauty' & 'Patharnakh' & 'Punjab Beauty' & 'Patharnakh' & 'Punjab Beauty' & 'Patharnakh' & 'Punjab Beauty' \\
\hline 0 & $83.73 \pm 2.87$ & $73.80 \pm 2.51$ & $109.13 \pm 5.14$ & $188.1 \pm 7.69$ & $27.33 \pm 0.31$ & $43.40 \pm 0.40$ & $94.00 \pm 1.40$ & $201.3 \pm 6.07$ \\
\hline 3 & $30.47 \pm 2.21$ & $37.47 \pm 3.95$ & $38.13 \pm 1.62$ & $51.27 \pm 4.57$ & $28.27 \pm 1.62$ & $44.20 \pm 0.92$ & $27.73 \pm 1.42$ & $52.27 \pm 0.50$ \\
\hline 6 & $26.67 \pm 0.95$ & $26.20 \pm 0.69$ & $52.60 \pm 2.27$ & $35.53 \pm 1.81$ & $30.07 \pm 1.72$ & $58.13 \pm 3.51$ & $43.07 \pm 1.94$ & $31.00 \pm 2.31$ \\
\hline 9 & $21.53 \pm 2.12$ & $1.27 \pm 0.12$ & $38.40 \pm 3.94$ & $45.73 \pm 1.89$ & $37.13 \pm 1.33$ & $83.80 \pm 1.44$ & $27.47 \pm 1.55$ & $44.87 \pm 2.96$ \\
\hline 12 & $4.47 \pm 0.42$ & $0.40 \pm 0.20$ & $54.47 \pm 5.62$ & $48.93 \pm 4.10$ & $31.93 \pm 3.19$ & $87.20 \pm 4.61$ & $58.80 \pm 1.77$ & $50.87 \pm 5.03$ \\
\hline Mean & $33.37 \pm 1.71$ & $27.83 \pm 1.49$ & $58.55 \pm 3.72$ & $73.92 \pm 4.01$ & $30.95 \pm 1.63$ & $63.35 \pm 2.18$ & $50.21 \pm 1.62$ & $76.05 \pm 3.37$ \\
\hline $\mathrm{CD}_{0.05}$ & 3.52 & 3.85 & 7.34 & 8.30 & 3.41 & 4.92 & 2.97 & 7.11 \\
\hline
\end{tabular}



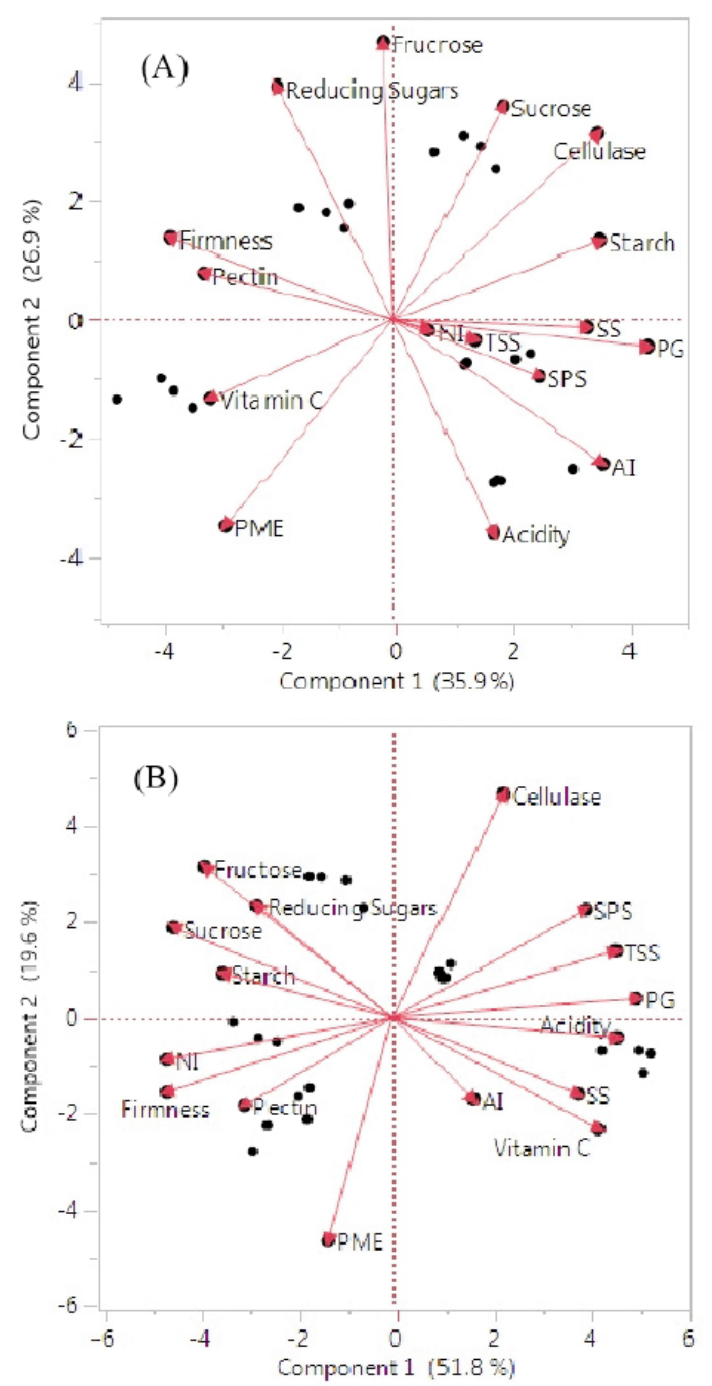

Fig. 6 - Biplot for quality parameters in pear fruits of 'Patharnakh' (A) and 'Punjab Beauty' (B) cultivars during storage at ambient conditions.

water pressure gradient between fruit tissues, environment, stage of ripening as well as storage temperature (Ma et al., 2014; Hafez et al., 2019). It acts as a detrimental factor to aggravate the fruit freshness, which might be associated with loss of moisture from the tissue (Barman et al., 2014). A nonsignificant relationship between SSC and weight loss in PatharNakh pear during storage was reported by Kaur et al. (2019). Fruit firmness is considered as an important index of texture and storage life of pears. Bhat et al. (2012) reported a significant reduction in pear fruit firmness with the lowest value after 15 days of storage. Softening of pear fruit during storage could be partly attributed to an increase in depolymerization and degradation of the cell-wall polysaccharides containing pectin, hemicellulose, and cellulose; and loss of moisture (Nath et al., 2011). Charoenchongsuk et al. (2015) observed a slight variation in Hunter values and hue angle of 'La France' pears during storage. Although $L^{*}, a^{*}, b^{*}$ and $C^{*}$ values showed an increasing trend with storage but these values are not considered for maturity indices of pear fruits. Increment in TSS content may be due to breakdown of organic polymers into simple sugars as reported by Mahajan and Singh (2014) or dehydration of fruits and transformation of pectic substances (Dave et al., 2017). Titratable acid content of fruit helps in keeping the fruit taste and flavor (Sajid et al., 2019). The increase in TA during storage may be due to conversion of sugars to organic acids and their utilization as a source of energy. Similar findings have been reported by Piga et al. (2003) in Cactus pear and 'Bartlett' pear (Bhat et al., 2012) during storage.

The reduction in sugars is characterized by higher respiration during storage; whereas, sugars and acids are readily used as substrates for metabolic processes (Ackermann et al., 1992) or fermentation of overripe fruits which converts sugars into alcohol (Kaur and Dhillon, 2015). The decrease in fructose content with advanced storage has also been reported by Chen et al. (2006) and Dave et al. (2017). SS, SPS and invertases enzymes substantially regulate sucrose synthesis in plants. These findings are corroborated with the observations reported by Chen et al. (2019) and they explained that activities of SS and SPS increased during initial storage period. Duan et al. (2019) reported that activities of SS cleavage and synthesis of isozymes was increased until 7 DAS in pears and subsequently, decreased during storage period. Itai et al. (2015) opined that higher activity of acid invertase from 6 to 12 DAS considerably declines sucrose content in Japanese pears. Acid invertase has the highest level during initial storage period in pear fruits (Itai and Tanahashi, 2008). A similar trend of $\mathrm{NI}$ activity was observed by Ren et al. (2020). The decline in sucrose content until 12 days of ambient storage (Fig. 3D) might be due to conversion into free sugars by various enzymes including SS and invertases (Itai and Tanahashi, 2008). These enzymes also exhibited similar trends in both the cultivars and high temperature improved their activities as shown in fruits of loquat (Wei et al., 2017). SPS synthesizes sucrose-6-phosphate molecule which results in the conversion to sucrose by sucrose- 6 -phophate phosphatase enzyme. Invertase enzymes cleave sucrose into glucose and fructose content. A positive correlation between SS and sucrose content in ' $\mathrm{PN}$ ' cultivar 
suggests that sucrose is synthesized during storage; whereas, a significant negative correlation between sucrose and SS, SPS and invertases depicts sucrose cleavage in 'PB' cultivar.

Cell wall degrading enzymes play an important role in fruit ripening. PME does not have pronounced effect on deviation in the texture of ripening fruit and partial demethylation of pectin occurs before PG causes significant hydrolysis. Thus, PME may function to prepare the substrate for hydrolysis by PG (Awad and Young, 1979). PG catalysis the hydrolysis of $(1 \rightarrow 4)$ galacturonan linkages of demethylated pectin and releases shorter chains, thereby causing the depolymerization and dissolution of pectin (Singh and Dwivedi, 2008), cell wall dissolution, and ultimately, fruit softening (Brummell et al., 2004). Cellulase acts on cell wall components such as cellulose and xyloglucan of hemicelluloses (Chen et al., 2015). In the present studies, the degradation of soluble pectin is related to the higher PG activity in the fruits during ambient storage resulting in softening of flesh. Zhou et al. (2011) also observed that a reduction in pectin content in pear fruits during storage might be due to higher depolymerization of cell wall polysaccharides and conversion of pectin's to nonsoluble form. Correlation studies revealed a negative relationship between fruit firmness, cellulase and PG enzymes in 'PN' and 'PB' cultivars. The activity of cellulase and PG enzymes increased in both the cultivars which causes decrease in fruit firmness with PG as main enzyme contributing to the degradation of cellwall polysaccharides. This relation revealed that the cell wall polysaccharides in pear were associated with the fruit softening.

In fruits, optimal concentration of $\mathrm{N}$ and $\mathrm{K}$ allows a proper development of peel color, fruit size, firmness, TSS, acidity, juiciness, flavor, and aroma. High N content reduces the fruit storability and $\mathrm{K}$ is also an important nutrient during storage of fruits to maintain K: Ca ratio (Brunetto et al., 2015). Lepaja et al. (2018) reported that 'Williams' pear fruit contains $7.83 \mathrm{mg} \mathrm{kg}^{-1} \mathrm{P}, 152.67 \mathrm{mg} \mathrm{kg}^{-1} \mathrm{~K}, 11.33 \mathrm{mg} \mathrm{kg}^{-1} \mathrm{Mg}$, $10.60 \mathrm{mg} \mathrm{kg}^{-1} \mathrm{Ca}, 1.11 \mathrm{mg} \mathrm{kg}^{-1} \mathrm{Fe}, 1.17 \mathrm{mg} \mathrm{kg}^{-1} \mathrm{Zn}$ and $1.14 \mathrm{mg} \mathrm{kg}^{-1} \mathrm{Cu}$ during storage. The concentration of

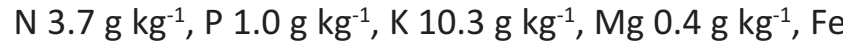
$15 \mathrm{mg} \mathrm{kg}^{-1}$, Mn $3.2 \mathrm{mg} \mathrm{kg}^{-1}$, Zn $8.9 \mathrm{mg} \mathrm{kg}^{-1}$ and Cu 6.1 $\mathrm{mg} \mathrm{kg}^{-1}$ was recorded in 'Rocha' pear fruit after storage for 22 days (Saquet et al., 2019).

Principal component analysis (PCA) is a multivariate technique to analyze the observations which are described by inter-correlated variables. The sugars are clustered together in one group indicating positive correlations with each other and juice acidity, SS and PG enzymes in second group had positive relationships but both groups had exhibited negative correlations during storage. Similar findings have been reported in pome fruits (Billy et al., 2008; LindaGarcia et al., 2019; Li et al., 2019).

This study represents the shelf-life of fruits of pear cultivars 'Patharnakh' and 'Punjab Beauty' during storage under ambient conditions. The results showed loss in weight, firmness, pectin and sugar content in fruits of both the cultivars. The activities of cellulase, PG and PME showed the positive effect on fruit softening; hence spoilage occurred during storage of fruits. It can be summarized from the results that reduction in sugar content and fastening of activities of cell-wall degrading enzymes between 6-9 days after storage in 'Patharnakh' and 3-6 days in 'Punjab Beauty' fruits makes them less desirable for further storage under ambient temperature conditions.

\section{References}

ACKERMANN J., FISCHER M., AMADO R., 1992 - Changes in sugars, acids, and amino acids during ripening and storage of apples (cv. Glockenapfel). - J. Agric. Food Chem., 40: 1131-1134.

AOAC, 1990 - Official and tentative methods of analysis. Association of Official Analytical Chemists, AOAC, VA, USA, pp. 965.

ASTHIR B., SINGH R., 1995 - Fluoride-induced changes in the activities of sucrose metabolizing enzymes in relation to starch accumulation in sorghum caryopsis, raised through liquid culture. - Plant Physiol. Biochem., 33(2): 219-223.

AWAD M., YOUNG R.E., 1979 - Postharvest variation in cellulase, polygalacturonase, and pectin methylesterase in avocado (Persea americana Mill, cv. Fuerte) fruits in relation to respiration and ethylene production. - Plant Physiol., 64(2): 306-308.

BALABAN M.O., ARREOLA A.G., MARSHALL M., PEPLOW A., WEI C.I., CORNEL J., 1991 - Inactivation of pectinesterase in orange juice by supercritical carbon dioxide. - J. Food Sci., 56:743-746.

BARMAN K., ASREY R., PAL R.K., JHA S.K., BHATIA K., 2014 Post-harvest nitric oxide treatment reduces chilling injury and enhances the shelf-life of mango (Mangifera indica L.) fruit during low-temperature storage. - J. Hort. Sci. Biotechnol., 89:3, 253-260.

BHAT M.Y., AHSAN H., BANDAY F.A., DAR M.A., WANI A.I., HASSAN G.I., 2012 - Effect of harvest dates, pre harvest calcium sprays and storage period on physico-chemical 
characteristics of pear cv. Bartlett. - J. Agric. Res. Dev., 2(4): 101-106.

BILLY L., MEHINAGIC E., ROYER G., RENARD C.M., ARVISENET G., PROST C., JOURJON F., 2008 Relationship between texture and pectin composition of two apple cultivars during storage. - Postharvest Biol. Technol., 47(3): 315-324.

BRADFIELD E.G., SPENCER D., 1965 - Leaf analysis as a guide to the nutrition of fruit crops: Determination of magnesium, zinc, and copper by atomic absorption spectroscopy. - J. Sci. Food Agric., 16(1): 33-38.

BRUMMELL D.A., DAL CIN V., CRISOSTO C.H., LABAVITCH J.M., 2004 - Cell wall metabolism during maturation, ripening and senescence of peach fruit. - J. Exp. Bot., 55: 2029-2039.

BRUNETTO G., MELO G.W.B.D., TOSELLI M., QUARTIERI M., TAGLIAVINI M., 2015 - The role of mineral nutrition on yields and fruit quality in grapevine, pear and apple. Rev. Bras. Frutic., 37(4): 1089-1104.

CHAROENCHONGSUK N., IKEDAA K., ITAIB A., OIKAWAA A., MURAYAMAA H., 2015 - Comparison of the expression of chlorophyll-degradation-related genes during ripening between stay-green and yellow-pear cultivars. - Sci. Hortic., 181: 89-94.

CHEN J.L., YAN S., FENG Z., XIAO L., HU X.S., 2006 Changes in the volatile compounds and chemical and physical properties of 'YaLi' pear (Pyrus bertschneideri Reld) during storage. - Food Chem., 97(2): 248-255.

CHEN M., LIN H., ZHANG S., LIN Y., CHEN Y., LIN Y., 2015 Effects of adenosine triphosphate (ATP) treatment on postharvest physiology, quality and storage behavior of longan fruit. - Food Bioproc. Tech., 8: 971-982.

CHEN Y., GE Y., ZHAO J., WEI M., LI C., HOU J., CHENG Y., CHEN J., 2019 - Postharvest sodium nitroprusside treatment maintains storage quality of apple fruit by regulating sucrose metabolism. - Postharvest Biol. Technol., 154: 115-120.

DAVE R.K., RAO T.R., NANDANE A.S., 2017 - Improvement of post-harvest quality of pear fruit with optimized composite edible coating formulations. - J. Food Sci. Technol., 54(12): 3917-3927.

DUAN B., GE Y., LI C., GAO X., TANG Q., LI X., WEI M., CHEN Y., 2019 - Effect of exogenous ATP treatment on sucrose metabolism and quality of 'Nanguo' pear fruit. - Sci. Hortic., 249: 71-76.

DUBOIS M., GILLES K.A., HAMILTON J.K., REBERS P.A., SMITH F., 1956 - Colorimetric method for the determination of sugars and related substances. - Anal. Chem., 28: 350-356.

GE Y., WEI M., LI C., CHEN Y., LV J., LI J., 2017 - Effect of acibenzolar-S-methyl on energy metabolism and blue mould of 'Nanguo' pear fruit. - Sci. Hortic., 225: 221225.

GEHRKE G.W., WALL L.L., ABSHEER J.S., 1972 - Preliminary report on the Gehrke-Wall automated nitrogen method for feeds. - Adv. Automat. Anal. Technicon Internat.
Congress, 7: 25.

HAFEZ O.M., SALEH M.A., THABET A.Y.I., EL-DAHSHOURI M.F., 2019 - Keeping 'Le Conte' pear fruits quality during storage life and marketing by using some natural medicinal plant extracts. - Eurasia J. Biosci., 13(2): 2203-2210.

HUNTER S., 1975 - The measurement of appearance. - John Wiley \& Sons, New York, USA, pp. 304-305.

ITAI A., HATANAKA R., IRIE H., MURAYAMA H., 2015 Effects of storage temperature on fruit quality and expression of sucrose phosphate synthase and acid invertase genes in Japanese pear. - Hort. J., 84 (3): 227232.

ITAI A., TANAHASHI T., 2008 - Inhibition of sucrose loss during cold storage in Japanese pear (Pyrus pyrifolia Nakai) by 1-MCP. - Postharvest Biol. Technol., 48(3): 355-363.

JACKSON M.L., 1973 - Phosphorus determination for soils, pp. 134-82. - In: JACKSON M.L. (ed.) Soil chemical analysis. Prentice Hall of India Pvt. Ltd, New Delhi, India, pp. 498.

KAUR A., GILL P.P.S., JAWANDHA S.K., SINGH M., 2019 Pre-storage exogenous application of boric acid extends storability and maintains quality of pear fruits. - Sci. Hortic., 256: 1-9.

KAUR K., DHILLON W.S., 2015 - Influence of maturity and storage period on physical and biochemical characteristics of pear during post cold storage at ambient conditions. - J. Food Sci. Technol., 52(8): 5352-5356.

KAUR M., SHARMA S., SINGH D., 2018 - Influence of selenium on carbohydrate accumulation in developing wheat grains. - Comm. Soil Sci. Plant Anal., 49: 1650-1659.

LEPAJA L., KULLAJ E., LEPAJA K., AVDIU V., ZAJMI A., 2018 Effect of water stress on some physiological indices in young pear trees. - XXX IHC International Symposium on Water and Nutrient Relations and Management of Horticultural Crops, August 12-16, Istanbul, Turkey, pp. 71-76.

LI M., ZHI H., DONG Y., 2019 - Textural property and cell wall metabolism of 'Golden Bosc' and 'd'Anjou' pears as influenced by oxygen regimes after long-term controlled atmosphere storage. - Postharvest Biol. Technol., 151: 26-35.

LINDA-GARCIA V., LARRIGAUDIERE C., ECHEVERRIA G., MURAYAMA H., SORIA Y., GINE-BORDONABA J., 2019 New insights on the ripening pattern of 'Blanquilla' pears: a comparison between on-and off-tree ripened fruit. - Postharvest Biol. Technol., 150: 112-121.

MA L., CAO J., XU L., ZHANG X., WANG Z., JIANG W., 2014 Effects of 1-methylcyclopropene in combination with chitosan oligosaccharides on postharvest quality of aprium fruits. - Sci. Hortic., 179: 301-305.

MAHAJAN B.V.C., SINGH K., DHILLON W.S., 2010 - Effect of 1-methylcyclopropene (1-MCP) on storage life and quality of pear fruits. - J. Food Sci. Technol., 47(3): 351354. 
MAHAJAN B.V.C., SINGH R., 2014 - Effect of packaging films on shelf life and quality of kinnow fruits packed in consumer packages. - Int. J. Farm Sci., 4(1): 92-98.

MALIK C.P., SINGH M.B., 1980 - Plant enzymology and histo-enzymology. - Kalyani Publishers, New Delhi, India, pp. 286.

NATH A., DEKA B.C., SINGH A., PATEL R.K., PAUL D., MISRA L.K., OJHA H., 2011 - Extension of shelf life of pear fruits using different packaging materials. - J. Food Sci. Technol., 49: 556-563.

OKIMASU S., 1956 - A new method for the quantitative determination of pectin in plant materials by colloid titration. - Bull. Agric. Chem. Soc., Japan, 20(1): 29-35.

PAU, 2020 - Package of practices for cultivation of fruits. PAU, Punjab Agricultural University, Ludhiana, India, pp. 56-64.

PIGA A., DEL CARO A., CORDA G., 2003 - From plums to prunes: influence of drying parameters on polyphenols and antioxidant activity. - J. Agric. Food Chem., 51: 3675-3681.

RANGANNA S., 2007 - Handbook of analysis and quality control of fruit and vegetable products. - Tata McGraw Hill Publishing Co Ltd., New Delhi, India, pp. 13.

REN G., RAN X., ZENG R., CHEN J., WANG Y., MAO C., WANG X., FENG Y., YANG G., 2020 - Effects of sodium selenite spray on apple production, quality, and sucrose metabolism-related enzyme activity. - Food Chem., 339: 127883.

SAJID M., BASIT A., ULLAH I., TAREEN J., ASIF M., KHAN S., ALI Q. S., GILANI S. A., ZEB S., NAWAZ M. K., 2019 Efficiency of calcium chloride $\left(\mathrm{CaCl}_{2}\right)$ treatment on postharvest performance of pear (Pyrus communis L.). Pure Appl. Biol., 8(2): 1111-1125.

SAQUET A.A., STREIF J., ALMEIDA D.P., 2019 - Mineral composition and distribution within 'Rocha' pear in relation to internal storage disorders. - Postharvest Biol. Technol., 158: 1-7.

SHARMA K.K., SINGH N.P., 2011 - Soil and orchard management. - Daya Publishers, New Delhi, India, pp. 377.

SINGH M.B., MALIK C.P., THAPAR N., 1978 - Changes in activities of some enzymes of carbohydrate metabolism in Amaryllis vittata pollen suspension cultures. - Plant Cell Physiol., 19: 677-684.

SINGH P., DWIVEDI U.N., 2008 - Purification and characterisation of multiple forms of polygalacturonase from mango (Mangifera indica cv. Dashehari) fruit. - Food Chem., 111(2): 345-349.

SINGH S., SINGH N.P., MAHAJAN B.V.C., SIDHU G.S., 2021 Response of strawberry fruits to low temperature and ambient storage conditions. - Indian J. Hort., 78(10): 111-117.

TAITI C., MARONE E., LANZA M., AZZARELLO E., MASI E., PANDOLF C., GIORDANI E., MANCUSO S., 2017 - Nashi or Williams pear fruits? Use of volatile organic compounds, physicochemical parameters, and sensory evaluation to understand the consumer's preference. - Eur. Food Res. Technol., 243(11): 1917-1931.

WEI Y., XU F., SHAO X., 2017 - Changes in soluble sugar metabolism in loquat fruit during different cold storage. - J. Food Sci. Technol., 54(5): 1043-1051.

YU L., LIU H., SHAO X., YU F., WEI Y., NI Z., XU F., WANG H., 2016 - Effects of hot air and methyl jasmonate treatment on the metabolism of soluble sugars in peach fruit during cold storage. - Postharvest Biol. Technol., 113: 8-16.

ZHOU R., LI Y., YAN L., XIE J., 2011 - Effect of edible coatings on enzymes, cell-membrane integrity, and cell-wall constituents in relation to brittleness and firmness of 'Huanghua' pears (Pyrus pyrifolia Nakai, cv. Huanghua) during storage. - Food Chem., 124(2): 569-575. 
